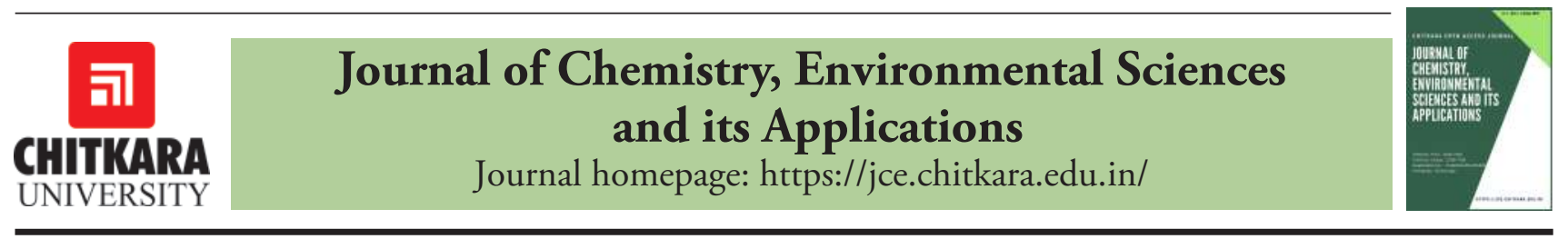

\title{
Climate Change Implication on Agricultural Growth
}

Dr Jagseer Singh

Lecturer in Geography, GSSS Mana Singh Wala, Firozpur, 142 052, Punjab, India

Email: jagseer@gmail.com

\section{ARTICLE INFORMATION}

Received: 05 June 2017

Revised: 17 June 2017

Accepted: 06 July 2017

Published Online: September 6, 2017

\section{Keywords:}

Greenhouse Gas, Environmental

Degradation, Consequences, Population,

Climate Change, Climate Variability,

Environmental Sustainability

DOI: https://doi.org/10.15415/jce.2017.41003

\begin{abstract}
Global climate change brings many disasters like floods and droughts which pose great danger to human life. Pollution and greenhouse gases also affect agriculture adversely. Environmental degradation occupies the place of utmost importance when it comes to green debate. Environmental pollution can be reduced greatly by providing bathing water, pure air quality and access to neat and clean drinking water. These measures will ensure that the ambitions of climatic health and valuable environment are achieved at the earliest.

In this research paper, I illustrate the international causes of degradation of environmental, climate change and its implication for agriculture growth. The paper argues that such certainty components can be projected by altering the current slowed perspectives on the problem talking the load from recent conceptual work on "cumulative change" as against" system change" to properly understand global environmental.

Change and environmental degradation, the paper presents an approach to identify and use the" certainty components" it is strong point is that it help to warming.

The research at hand is a review on the study survey associated by reduction of environment risk, water, air pollution, enhanced quality of water and betterment of climate factors.
\end{abstract}

\section{Introduction}

Our health is related to the environment in which we exist. The environmental hazards and climate change impact human health directly and indirectly- directly our suffering due to harmful factors and indirectly by distorting our environment. The effect of depletion of natural resources such as water, air and soil is called environmental degradation. Climate change and environmental degradation are responsible for extinction of wildlife. The High Level panel lists environmental degradation and climate change among top threats facing the world today. The international body defines environmental degradation as the dwindling capacity of environment to fulfil our social and ecological needs.

Human disturbance is the main reason behind global warming and environmental degradation. The biodiversity, flora and fauna that inhibit are the factors that determine the intensity of global warming and the impact on environment. Human activities also contribute greatly to the cause. Modern urbanization, industrialisation, and population explosion are the major causes of environmental pollution and climate change. Irresponsible human behaviour has proved fatal to the human existence itself.
Excessive use of automobiles and release of pollutants in the form of smoke have made air unfit for breathing. The population explosion, especially in urban areas has resulted in increased per-capita-automobile numbers, the use of which releases poisonous gases like cfcs, nitrogen oxide and carbon monoxide among many others. The earth's temperature is rising day by day resulting in its getting warmer gradually. The polar ice cap is melting faster than ever. This is the direct result of man's interference with nature.

\section{Objectives of Study}

- Reduction in Greenhouse gas emissions and adaptation to climate change.

- Implementation of International and EU commitments on climate change, protection of the ozone layer and regulation and monitoring of fluorinated greenhouse gases.

- Coordination of climate change policy issues.

- Project implementation- funding of projects $\&$ actions on climate change.

- To initiate programs to create environmental awareness and a healthy earth.

- To work for cleaner and healthier urbanization. 
- To reinforce rehabilitation of victims of environmental disasters.

\section{Area of the Study}

Air pollution, water pollution, climate change, land degradation, garbage and pollution of natural environmental are the issues that demand immediate attention. These have already caused irreparable harm to nature. Between 1947 through 2011, utmost damage was done. Though, it brings a bit of satisfaction when we see that between 2011 through 2015, speedy steps were taken to address the burning issues like global warming, land degradation and pollution of all kinds. Environmental factors greatly impact the primary issues of disease, health and sustained livelihood in India. The agricultural productivity in the same region of India.

Table 1. Land use pattern in India - 1981-2011.

\begin{tabular}{|c|c|c|c|c|}
\hline Category & $1980-81$ & $1990-91$ & 2000-01 & 2010-11 \\
\hline $\begin{array}{l}\text { Statistical data of } \\
\text { Utilization Land }\end{array}$ & 304.75 & 305.70 & 306.01 & 307.11 \\
\hline Forest & 67.47 & 67.80 & 68.02 & 75.10 \\
\hline $\begin{array}{l}\text { Un-cultivated area } \\
(1+2)\end{array}$ & 41.57 & 42.51 & 43.09 & 42.55 \\
\hline $\begin{array}{l}1 \text { - Not use in } \\
\text { agriculture }\end{array}$ & 20.61 & 22.09 & 23.02 & 23.01 \\
\hline $\begin{array}{l}\text { 2- Uncultivated } \\
\text { area }\end{array}$ & 20.96 & 20.42 & 20.07 & 19.54 \\
\hline $\begin{array}{l}\text { Uncultivated } \\
\text { with follow land } \\
(1+2+3)\end{array}$ & 30.1 & 30.34 & 28.71 & 26.62 \\
\hline $\begin{array}{l}\text { 1- Perpetual } \\
\text { posture with glazy } \\
\text { land }\end{array}$ & 10.96 & 10.67 & 10.47 & 10.30 \\
\hline $\begin{array}{l}\text { 2- Area with crops } \\
\text { not showing net } \\
\text { areas }\end{array}$ & 3.40 & 3.67 & 3.51 & 3.41 \\
\hline $\begin{array}{l}\text { 3- Cultural waste } \\
\text { land }\end{array}$ & 15.74 & 16.00 & 14.73 & 12.91 \\
\hline
\end{tabular}

Source: Dept of Agri \& cooperation - 2012

\section{Data Base and Methodology}

Secondary data forms the basis of this study. This data has taken from various sources of books and internet. These secondary data were collected from published and unpublished documents of government like water resources Department, Remote sensing models, India and various countries of environmental protection agency, climatological Department of India.

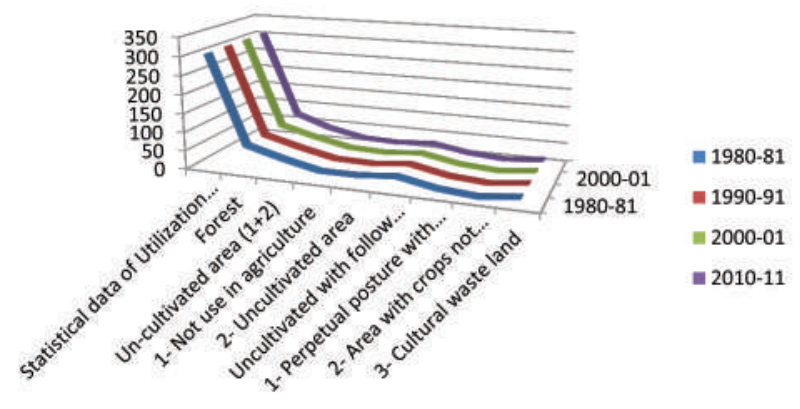

Figure 1. Land use pattern in India.

\section{Discussion}

Indian agriculture is greatly impacted by the change in the climate. In our country, the food grain production has increased spectacularly due to the green revolution from $55 \mathrm{mt}$ in 1951 to $220 \mathrm{mt}$ in 2011 and the mean cereal production has improved from $550 \mathrm{~kg} /$ ha to almost 2060 $\mathrm{kg} / \mathrm{h}$ (Govt. of India 2011). This transformation happened as a result of increase in cultivable area, use of new high yielding semi-dwarf varieties since the early 1960 and better and enhanced application of irrigation, fertilizers and pesticides supported by progressive government policies. Currently, Indian agriculture has 200 million ha gross sown area (150 million ha net sown area) and $43 \%$ of this is irrigated. Eggs, fish, milk, sugar and a few other crops have also seen a great spurt in production.

By 2060, there might be a food crisis owing to population explosion. India's population is projected to grow to 1.8 billion.(Ministry of Environment and Forest, 2004). This alarming rise in population will result in a greater demand for food. The demand for rice and wheat, the pre dominant staple foods is expected to increase to 125 $\mathrm{mt}$ and $135 \mathrm{mt}$, respectively by 2022 even if the income growth is moderate. Owing to dearth of additional land for cultivation, the demand for pulses, fruit, vegetable, milk, meat and eggs poses a great challenge. It is projected that the average yields of cultivable eatables need to increase by 58 , 64, 38 and 169\% respectively, by 2022. (Statistical report 1981-2001, New Delhi)

What further compounds the problem is the fact that the areas which largely benefitted from the green revolution happen to be the sufferers of environmental degradation. compounding the problem. Decline in the quality of underground water and soil fertility are main threats. The farmers have to put in much more efforts to realize the same yield as achieved 30-32 years ago.(NAAS, 2009). The mushrooming of tubewells in last three decades has resulted in an over consumption of ground water in many blocks 
leading to alarming decline in water table. On the other hand, rising water table in some canal-irrigated districts has compounded the salinity problem. In the present century, increase in food production to be in direct proportional to poverty reduction and environmental preservation is the greatest challenge facing us.

\subsection{Environmental Challenges}

At the root of most of environmental problems are the factors like population growth and economic development. Some other factors are habitat destruction pressure on land and loss of biodiversity, changing consumption pattern rising demand for energy, air pollution, land and soil degradation, forests, environmental degradation, global warming, and climate change and water scarcity and water pollution.

\subsection{Pressure of Land}

Scarcity of agricultural land stares us in the face. Today every million hectares of land supports 7.28 million people. Forty four percent of cultivable land is one of the highest in the world. Variation in usable land pattern requires altering the proportion of area under portions and time periods.

\subsection{Degradation of Land}

The degradation of land is one from or the other is matter of serious concern endangering sustainability of Agriculture. Landslides in hilly areas and deforestation, over grazing and other faulty cultural practices are the major reason. It may be seen from Table 2 out of total geographical area, 144.3 million hectare $(10.3 \%)$ area is subject to such water and wind erosion.(ISDR 2004-03-31)

Table 2. Soil erosion and land Degradation:- (2000-01).

\begin{tabular}{llll}
\hline $\begin{array}{l}\text { Sr. } \\
\text { No }\end{array}$ & Category & $\begin{array}{l}\text { Million } \\
\text { hectors }\end{array}$ & $\begin{array}{l}\text { \% of cultivation } \\
\text { area }\end{array}$ \\
\hline 1. & $\begin{array}{l}\text { Total area under } \\
\text { cultivation }\end{array}$ & 328.6 & 100.00 \\
2. & $\begin{array}{l}\text { Vulnerable areas } \\
\text { with erosion of }\end{array}$ & 144.4 & 4.3 \\
& water and wind & & \\
3. & Water logged area & 8.9 & 2.8 \\
4. & Alkali soil & 3.8 & 1.2 \\
5. & Acid soil & 4.7 & 1.5 \\
6. & $\begin{array}{l}\text { Saline soil including } \\
\text { coastal sandy area }\end{array}$ & 6.2 & 1.7 \\
7. & Ravines and gullies & 4.5 & 1.2
\end{tabular}

\begin{tabular}{|c|c|c|c|}
\hline 8. & $\begin{array}{l}\text { Area subject to } \\
\text { shifting cultivation }\end{array}$ & 5.4 & 1.6 \\
\hline 9. & $\begin{array}{l}\text { Riverine and } \\
\text { torrents }\end{array}$ & 3.1 & 0.9 \\
\hline & Total (3to 9) & 36.6 & 10.9 \\
\hline
\end{tabular}

Source: Economic survey of India , 2002-03

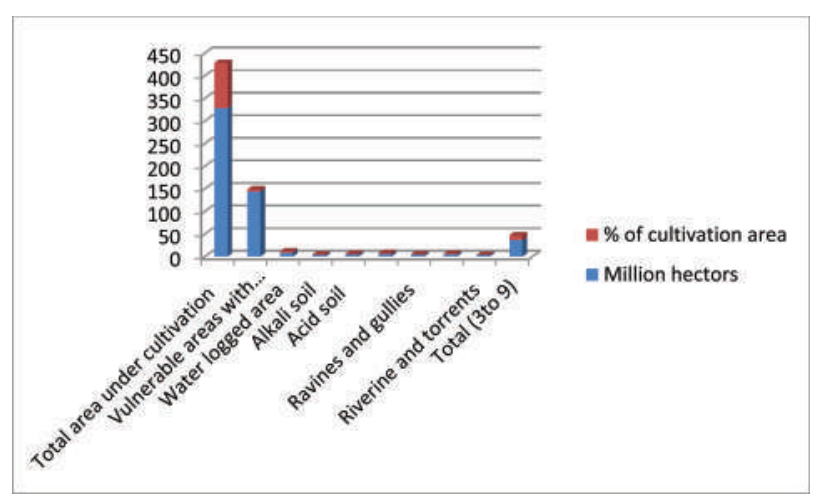

Figure 2. Cultivation Area of Soil Erosion \& Land Degradation 2000-2001.

Water logging due to rising water table, particularly along the rivers, rendering soil unfit for cultivation, cover 10.9 million hectare land. In the same way, overdependence on modified agriculture and irrigation also resulted in deterioration of water quality in the same migrated area of the county. Therefore apart from problem soils farming a significant part of the total area, the following are the kinds of land degradation taking place-

- Deficiency of soil nutrients due to intensive cultivation.

- Imbalance in soil nutrients particularity the deficiency of micronutrients.

- Decline in the organic matter in the soil.

- Decline in underground water due to over exhaustion for high water using crops, increase in copping intensity and increase in cultivated area especially is northern part of the sweet water zone.

- High use of nitrogen and water have caused percolation of nitrogen up to water table thus polluting it even for human consumption.

\subsection{Deforestation}

The main reason for decline in forest wealth are -

- Increase in population resulting in more demand for fuel wood and timber.

- Indiscriminate siting of development projects.

Of the total global carbon emissions, cars and frocks are roughly $14 \%$ contributors and deforestation is responsible for $15 \%$ of the same (Attrib. WCN). 


\subsection{Deforestation and its Extreme Effect on Global Warming}

31.9 million acres of tropical rainforest mane was cut down each year between 2001 and 2011. We need to urgently change the present system of irresponsible cutting of trees. According to the Environment Defence System, another 200 billion tons of carbon will be released into the atmosphere as a result of deforestation in coming decades.

\section{Result \& Discussion}

- Global warming has increased the frequency of temperature, storms, heat waves, droughts and floods.

- Changes in the frequency and severity of drought, the growth of $\mathrm{CO} 2$ and reducing Green House gases in the environment.

- Global warming such as changes of tropical deforestation, forest fires, biotic adaptations to warming and agricultural implications.

- Green House gases like Methane, Carbon Dioxide, Nitrous Oxide, Chlorofluorocarbons, water vapours that have severely impacted the heat balance of the earth.

- Global warming such as changes of tropical deforestation, forest fires, biotic adaptations to warming and agricultural implications.

- Global warming is caused by green house effect in earth's near-surface atmosphere.

- Irresponsible human behaviour is solely responsible for the presence of Green House gases such as CO2, Methane, CFCs and Nitrous Oxide in the atmosphere.

- The burning of fossil fuels adversely impacts the atmosphere.

\section{Annual Greenhouse Gas Emissions by Sector}

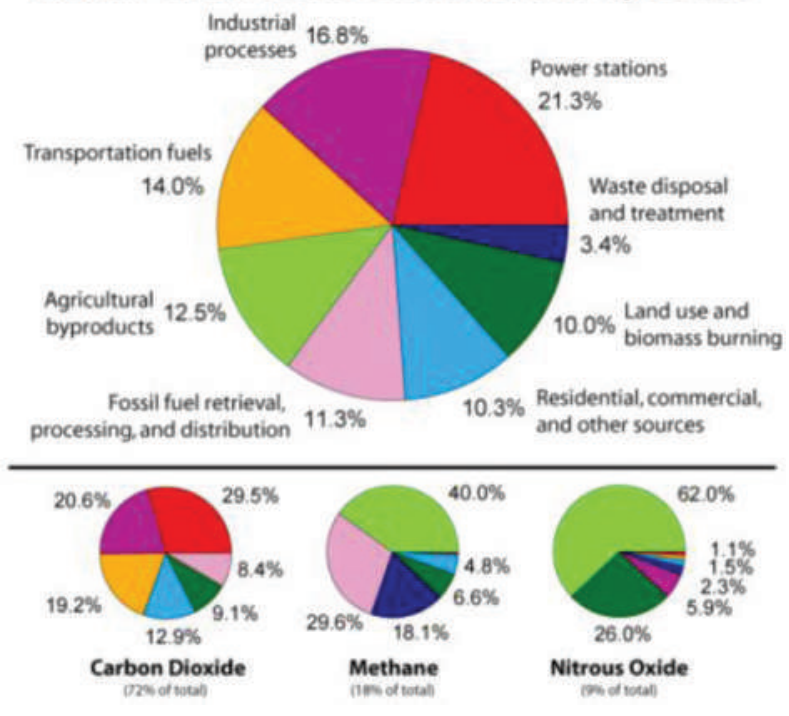

\section{Overview of Results}

The root problem of this environmental imbalance seem to be the rich and the powerful, who have pushed everyone else to the margins and plundered the natural beauty of earth for their own benefits. The situation is already spiralling out of control, but the situation is expected to grow worse in the next 50-60 years. If we are to survive, health policies need to be linked directly to the environment. This field holds a lot for further improvement as it has remained neglected for a long time. (Statistical abstract of India, New Delhi)

\section{Solution of Deforestation}

- $\quad$ Curbing the felling of trees with the help of stern laws and rules is the most viable solution.

- As deforestation is a money-churner, the financial benefits associated with it is going to be a big hindrance in the effective implementation of laws against deforestation.

- The next practical solution is the clear cutting of forests. This will be of immense help in achieving this objective.

- New saplings should be planted as soon as the trees are cut. If possible, the ration should be 4 to 1 .

Solution of Global Warming:- It is increase in the temperature of the earth. The main reason is the emission of green house gases in the earth's atmosphere. The melting of ice in the Antarctica and the Himalayas is the direct result of this. With the gradual increase in the water level of oceans and western winds becoming very strong, it is becoming increasingly difficult to survive. This will eventually result in more frequent occurrence of floods and droughts. (A.N. Sarkar)

Raise awareness:- The first thing to do for the prevention of global warming is to make people of every country aware about its If we successful in doing so, it will help us to prevent global warming from spreading awareness. Clearly, has a critical role to play in the reduction of Global Warming.

Reduce Carbon foot print:- In order to save the planet earth, we need to keep the environment around us away from pollution as much as possible. Remember that whatever has been happening to the environment human activities are the culprit for it. We have to make our earth 'Green' in the true sense. The 'carbon foot print' will have to be reduced. With responsible and reduced use of refrigerators, air conditioners etc., the emission of $\mathrm{CFC}$ gases can be reduced to a great extent. Adherence to strict environmental standards is most essential. (www. Greenpeace.org/.../solution)

Plants and conserve trees:- It is necessary to plant trees to save the soil, ensure clean air and environment. Today, to meet 
the demands of urbanization, trees are cut indiscriminately. Trees are the largest source of oxygen and we, ironically, cut them instead of growing them. Tree plantations can be one of the great solutions of Global warming.

During the process of photosynthesis, trees not only give oxygen but also absorb carbon dioxide, which is the main source of global warming, we should make the world aware of the need for planting more and more trees.

Go for alternative energy:- One of important ways to stop global warning includes the need for renewable energy measures i.e wind energy, solar energy and hydroelectricity instead of the electricity produced by coal. If we use solar energy, then the use of water is reduced, and if helps keep the earth remain green.(Singh, Savinder, Climatology, Allahabad, 2005)

Save the agricultural land:- As the work force tends to buy or take rented accommodation near their offices, concrete jungles come up to evolve in the entire area. With the result, rain water does not go to the ground and collects at a single place through the drains and contaminates the rivers, and also other small reservoirs.

New industries should be set up in places where agriculture is not being cultivated. This will help us maintain the earth's green cover. To prevent the illeffects of global warming, we need to reduce the proportion of greenhouse gases in the atmosphere. For this, it is necessary that we minimize the use of fossil fuels by controlling vehicular and industrial emissions. We have to use sources of energy in which carbon is used in a limited amount or not at all such as solar energy, nuclear energy and wind energy etc. Trees should be protected from cutting and more trees should be planted as they are the biggest help in our fight against global warming. (Lal D.S.Climatology, 1986)

\section{Conclusion}

Population growth results in increasing number of people who live in utter poverty, increasing population concentration and immense pressure on natural resources. This has resulted in dwindling natural resource base. Population pressure on arable land contributes to the continually shrinking productive resource base of the economy. Population and poverty control are the need of the hour. Without it, the health of the people will be at stake. Natural resources and technology also need a suitable environment to survive. For us to survive and leave a healthy environment for our children, we need to protect natural habitat and natural resources.
One cannot expect the total global food production to change much as a result of climate, but it can bring suatainable changes to regional food production. Some areas may see increased crop production while the others may show decline. Countries like India may be in a better position to adapt to the new circumstances. Developing countries may be the worst sufferers. Recycling and the production of disposable products may go a long way in balancing the situation that has been worsening since decades. If urgent steps are not taken in this direction, our next generations will suffer badly.('Green Data Book' The World Bank, 2010)

\section{References}

"Environment assessment, country data; India," the world Bank, 2011.

"Global forest resources assessment, 2010, FAO 2011"

"India; country strategy paper: 2007-2013" European external action service, European Union.2007"

"ISDR: Terminology;" the international strategy for disaster reduction 2004-03-31.

"The little Green Data Book." The world Bank, 2010

Central Statistical Organization (1999)," Statistical abstract of India." Ministry of Statistics and Programme Implementation, Govt. of India, New Delhi."

Dept of Agri \& Cooperation (2002)."India Agri.in Brief" Directorate of economics and statistics, ministry of Agri, Govt. of India, New Delhi.

Registrar General of India (1981-2001); Sample Registration System, Statistical reports 1981-2001,

Gupta, Rajiv and Selvans: Global Warming and Climate Change (2012)

Lal, DS: Climatology, Chaitanya, Allahabad, 1986

Garrison, T: Oceonagraphy-

Sarkar (AN): Global Climate Changed Sustainable Energy

Peterson, S.: Introduction to Meteorology, Mc Graw Hill, London, 1969

Singh Savinder, Climatology, Prayag Pustak Bhawan, Allahabad, 2005

Singh Savinder, Oceanography, Prayag Pustak Bhawan, Allahabad, 2008

India Meteorological Department: Climatological Tables of Observations in India, Govt. of India, 1968

Falkner (Robert): The Handbook of Global Climate and Environmental Policy (2013)

NIPCC (Non-governmental International Panel of Climate Change)

Academic Reference to Climate Change Reconsidered www.worldcarfree.net;EDF 